\title{
Chemical speciation of carbon in municipal solid waste incinerator residues
}

\author{
Stefano Ferrari, Hasan Belevi*, Peter Baccini \\ Swiss Federal Institute for Environmental Science and Technology (EAWAG), CH-8600 Dubendorf, Switzerland
}

Accepted 7 July 2001

\begin{abstract}
Incinerators do not achieve a complete mineralization of organic constituents of municipal solid waste. The solid residues (bottom ash, boiler ash and air pollution control residues) contain carbon which can be determined as total organic carbon (TOC). This work focuses on the TOC composition and its significance to the genesis and diagenesis of the solid residues. An analytical procedure is presented to characterize carbon species by different chemical and microscopic analytical methods. The procedure is based on two steps. In the first step a quantitative classification of TOC into four different carbon species (elemental carbon, water extractable organic carbon, dichloromethane extractable organic carbon and non extractable organic carbon) is performed to obtain a first survey of the TOC composition. Based on this survey a further characterization of individual carbon species is performed. The results of the qualitative and quantitative characterization of carbon species allow to postulate hypotheses on the influence of organic carbon on the long-term behavior of the solid residues. (C) 2002 Elsevier Science Ltd. All rights reserved.
\end{abstract}

\section{Introduction}

A major objective of municipal solid waste (MSW) incineration is the complete mineralization of the organic constituents of MSW [1,2]. This objective is not achieved yet $[3,4]$. In a study on the MSW incinerator plant of St. Gallen, Switzerland, it was found that about 98 to $99 \%$ of carbon is converted to carbon dioxide by combustion, between 1 and $2 \%$ is transferred to the bottom ash and between 0.1 and $0.4 \%$ to the boiler ash and air pollution control residues [5]. Total organic carbon (TOC) content of the solid residues ranges between 2 and $50 \mathrm{~g} \mathrm{~kg}^{-1}$ dry matter (DM) [3,4,6].

Organic carbon represents a potential for chemical and microbiological processes in landfills. It is suspected to have a significant influence on the long-term behavior of the solid residues [4,7]. In laboratory experiments, it has been shown that organic carbon in bottom ashes can be degraded by microorganisms under alkaline conditions which are expected during decades to centuries in bottom ash monofills [7]. At the same time, the

* Corresponding author. Tel.: +41-1-823-55-14 ; fax: +41-1-82353-99.

E-mail address: belevi@eawag.ch (H. Belevi).
$\mathrm{pH}$ of bottom ash extracts decreased from initially 10.5 to 8.3 after $336 \mathrm{~h}$ incubation time. The authors of this study therefore concluded that microbial degradation of organic carbon may accelerate the mobilization of heavy metals, since $\mathrm{pH}$ is one of the major parameters controlling the leaching of many heavy metals. Concentrations of some heavy metals can be expected to rise when leachate $\mathrm{pH}$ values decrease [8]. A second possible influence of organic carbon on the long-term behavior of solid residues concerns the complexation and mobilization of metals with organic ligands $[9,10]$.

In order to achieve a better estimation about the influence of organic carbon on the long-term behavior of the solid residues, more information is needed about the TOC composition. Until now, the knowledge referring to this point was scarce. Most efforts focused on the toxic organic micropollutants such as polychlorinated dibenzo-p-dioxins and dibenzofurans, polychlorinated biphenyls or polyaromatic hydrocarbons [11-13]. In electrostatic precipitator dust, more than 600 different compounds have been detected, from which more than 200 could be identified hydrocarbons [11,12]. However, the sum of these micropollutants make up only a small part of about $1 \%$ or less of the TOC [6]. Only a few studies attempted to investigate the more abundant substances [14,15]. 
In this paper an analytical procedure is presented which allows a chemical characterization of the main components of organic carbon.

\section{Experimental section}

\subsection{Sampling and sample preparation}

Bottom ash, boiler ash and electrostatic precipitator dust (EPD) have been sampled at the four MSW incinerators of Hinwil, Oftringen, Winterthur, and Hagenholz (Zurich) in Switzerland. The samples are accordingly abbreviated $\mathrm{H}$ (Hinwil), $\mathrm{O}$ (Oftringen), W (Winterthur) and HH (Hagenholz). A selection of significant process engineering parameters concerning the four incinerators are listed in Table 1.

With the exception of sample W3 (Table 2), all bottom ash samples were taken after being quenched. Over a time period of $1 \mathrm{~h}$, the bottom ash was withdrawn from the conveyer belt by a shovel and heaped up to a cone of about $300 \mathrm{~kg}$. The cone was then thoroughly mixed and divided into two parts. One part was rejected while the other one was again mixed and divided. This procedure was repeated until the sample amounted to about $20 \mathrm{~kg}$. Boiler ash and EPD samples were taken from the outlet of a collecting funnel, from a conveyer belt or from the inside of the boiler and electrostatic precipitator with the aid of a collecting receptacle. Details about the sampling procedures have been described elsewhere [6]. After sampling bottom ash samples were weighed, freed from rough metal pieces and dried at $70{ }^{\circ} \mathrm{C}$ to constant weight. Samples were ground in a steel ball mill for $2 \mathrm{~h}$. Unburned organic material such as textiles, rubber or plastics which are not crushed in the first grinding step were frozen with liquid nitrogen and ground separately. Finally the fractions were collected and thoroughly mixed. Boiler ash and EPD were dried at $70{ }^{\circ} \mathrm{C}$ until constant weight. Grinding was performed in a zirconia ball mill for 15 min. All samples were ground to a grain size $<0.2 \mathrm{~mm}$.

\subsection{Analytical procedure for carbon speciation}

The procedure for the chemical speciation of carbon is presented in Fig. 1. First total carbon (TC) and carbonate carbon (CC) were determined quantitatively. Total organic carbon (TOC) is defined as the difference between TC and CC [3,4]. A first qualitative investigation of TOC was obtained with the help of thermogravimetry-mass spectrometry. Then TOC was subdivided quantitatively into organic carbon (OC) and elemental carbon (EC). According to its operational definition, TOC includes not only organic but also elemental carbon. EC is a constituent of soot which is formed during incomplete combustion processes [16]. In the next step, organic carbon was further subdivided by sequential extraction into three fractions: water extractable organic carbon $\left(\mathrm{EOC}^{\mathrm{H}_{2} \mathrm{O}}\right)$, dichloromethane extractable organic carbon $\left(\mathrm{EOC}^{\mathrm{CH}_{2} \mathrm{Cl}_{2}}\right)$ and non extractable organic carbon (NEOC). With water as solvent three sequential extraction steps at $\mathrm{pH} \mathrm{12,7}$ and 2 were carried out. According to the analytical scheme in Fig. 1, TOC was subdivided into four different fractions. The following simple equations are valid:

Table 1

Process engineering parameters of the municipal solid waste (MSW) incinerators of Hinwil, Oftringen, Winterthur and Hagenholz (Zurich)

\begin{tabular}{|c|c|c|c|c|c|}
\hline Parameter & Unit & $\begin{array}{l}\text { MSWI } \\
\text { Hinwil }\end{array}$ & $\begin{array}{l}\text { MSWI } \\
\text { Oftringen }\end{array}$ & $\begin{array}{l}\text { MSWI } \\
\text { Winterthur }\end{array}$ & $\begin{array}{l}\text { MSWI } \\
\text { Hagenholz }\end{array}$ \\
\hline Grate type & & $\begin{array}{l}\text { Martin } \\
\text { reciprocating grate }\end{array}$ & $\begin{array}{l}\text { Noell } \\
\text { traveling grate }\end{array}$ & $\begin{array}{l}\text { Martin } \\
\text { reciprocating grate }\end{array}$ & $\begin{array}{l}\text { Widmer + Ernst } \\
\text { traveling grate }\end{array}$ \\
\hline Grate width & $(\mathrm{m})$ & 4.2 & 4.2 & 6.3 & 6.5 \\
\hline Grate length & (m) & 7.1 & 9.6 & 9.1 & 9.3 \\
\hline Effective grate area & $\left(\mathrm{m}^{2}\right)$ & 30 & 40 & 57 & 61 \\
\hline Grate inclination & $\left({ }^{\circ}\right)$ & 26 & 6 & 26 & 0 \\
\hline Grate cooling system & & Primary air & Primary air and water & Primary air & Primary air \\
\hline \multicolumn{6}{|l|}{ Waste throughput } \\
\hline Max. & $\left(\mathrm{t} \mathrm{h}^{-1}\right)$ & 10 & 10 & 16 & 19 \\
\hline Min. & $\left(\mathrm{t} \mathrm{h}^{-1}\right)$ & 5.5 & 5.0 & 9.0 & 11 \\
\hline Maximal heat release rate & (MW) & 22 & 28 & 48 & 44 \\
\hline Maximal steam production & $\left(\mathrm{t} \mathrm{h}^{-1}\right)$ & n.d. & 35 & 54 & 45 \\
\hline Percentage directly delivered waste ${ }^{\mathrm{a}}$ & $(\%)$ & 40 & $40-50$ & 60 & 50 \\
\hline Mean residence time of waste on the grate & $(\min )$ & 60 & 90 & $40-90$ & n.d. \\
\hline Air supply in combustion chamber & & Counter current flow & Counter current flow & Counter current flow & Central current flow \\
\hline Rate of primary to secondary air & & $2: 1$ & $2: 2.7: 1^{\mathrm{b}}$ & $2: 1$ & $2: 1$ \\
\hline Schredder for break up of bulky goods & & no & yes & yes & yes \\
\hline
\end{tabular}

n.d.: no declaration.

a Percentage of directly delivered waste from industry, trade and building trade relative to total waste.

b Primary air/side plate air/secondary air. 
$\mathrm{TOC}=\mathrm{TC}-\mathrm{CC}$

$\mathrm{TOC}=\mathrm{OC}+\mathrm{EC}$

$\mathrm{OC}=\mathrm{EOC}^{\mathrm{H}_{2} \mathrm{O}}+\mathrm{EOC}^{\mathrm{CH}_{2} \mathrm{Cl}_{2}}+\mathrm{NEOC}$

$\mathrm{TOC}=\mathrm{EC}+\mathrm{EOC}^{\mathrm{H}_{2} \mathrm{O}}+\mathrm{EOC}^{\mathrm{CH}_{2} \mathrm{Cl}_{2}}+\mathrm{NEOC}$

The different TOC fractions were investigated using a number of suitable techniques (Fig. 1).

\subsection{Elemental analysis and bulk parameters}

Quantitative determination of TC and total hydrogen (TH) were carried out using a CHNS-CombustionAnalyzer (Carlo Erba 1500 and 1108). Calibration of peak areas was accomplished with sulfanilic acid. Carbonate carbon was determined by coulometric analysis (Coulometrics 5011) using $\mathrm{Na}_{2} \mathrm{CO}_{3}$ as reference compound. Quantitative determination of dissolved organic carbon (DOC) was performed using a DOC-Analyzer (Shimadzu 5000A). Water extracts were filtered through a $0.45 \mu \mathrm{m}$ cellulose nitrate membrane filter, acidified with $5 \mathrm{M} \mathrm{HCl}$ to $\mathrm{pH} 2$ and gassed with $\mathrm{N}_{2}$ to remove carbonates. In order to calibrate peak areas, reference solutions of potassium hydrogen phthalate were used.

\subsection{Thermogravimetry-mass spectrometry ( $T G-M S)$}

Thermogravimetric analyses were carried out using a thermobalance (Perkin Elmer TGS-2) complemented with a quadrupol mass spectrometer (Balzers QMG511) [17]. Experiments were accomplished under oxidizing atmosphere $\left(\mathrm{O}_{2}\right)$ and under inert atmosphere $(\mathrm{He})$.

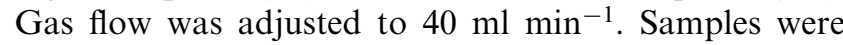
heated up with a heat rate of $20{ }^{\circ} \mathrm{C} \mathrm{min}^{-1}$.

\subsection{Quantitative determination of elemental carbon}

In order to determine EC quantitatively, a pyrolysis and combustion equipment was developed. The apparatus consists of two furnaces in series that are connected by a quartz tube with a diameter of $20 \mathrm{~mm}$. The oxidation or pyrolysis takes place in the first furnace. The gaseous products are completely oxidized in the second furnace at $800{ }^{\circ} \mathrm{C}$ by supplying additional oxy-

Table 2

Contents of carbon species $\mathrm{EC}, \mathrm{EOC}^{\mathrm{H}_{2} \mathrm{O}}, \mathrm{EOC}^{\mathrm{CH}_{2} \mathrm{Cl}_{2}}$ and $\mathrm{NEOC}$ and relative contribution to $\mathrm{TOC}$ of solid residues

\begin{tabular}{|c|c|c|c|c|c|c|c|c|c|c|}
\hline \multirow[t]{2}{*}{ Sample } & \multirow[t]{2}{*}{$\mathrm{Nr}$. } & \multirow{2}{*}{$\frac{\text { TOC }}{\left(\mathrm{g} \mathrm{kg}^{-1} \mathrm{DM}\right)}$} & \multicolumn{2}{|l|}{ EC } & \multicolumn{2}{|l|}{$\mathrm{EOC}^{\mathrm{H}_{2} \mathrm{O}}$} & \multicolumn{2}{|l|}{$\mathrm{EOC}^{\mathrm{CH}_{2} \mathrm{Cl}_{2}}$} & \multicolumn{2}{|l|}{ NEOC } \\
\hline & & & $\left(\mathrm{g} \mathrm{kg}^{-1} \mathrm{DM}\right)$ & $(\%)^{\mathrm{a}}$ & $\left(\mathrm{mg} \mathrm{kg}^{-1} \mathrm{DM}\right)$ & $(\%)^{\mathrm{a}}$ & $\left(\mathrm{mg} \mathrm{kg}^{-1} \mathrm{DM}\right)$ & $(\%)^{\mathrm{a}}$ & $\left(\mathrm{g} \mathrm{kg}^{-1} \mathrm{DM}\right)$ & $(\%)^{\mathrm{a}}$ \\
\hline \multirow[t]{11}{*}{ Bottom Ash } & $\mathrm{H} 1$ & $13.6 \pm 1.3$ & $9.1 \pm 0.2$ & 67 & $1360 \pm 40$ & 10 & $433 \pm 32$ & 3 & $2.7 \pm 0.3$ & 20 \\
\hline & $\mathrm{H} 2$ & $12.0 \pm 0.4$ & $8.4 \pm 0.4$ & 70 & $1198 \pm 32$ & 10 & $271 \pm 22$ & 2 & $2.1 \pm 0.1$ & 18 \\
\hline & $\mathrm{H} 3$ & $14.8 \pm 3.6$ & $9.8 \pm 0.3$ & 66 & $1549 \pm 49$ & 11 & $267 \pm 22$ & 2 & $3.2 \pm 0.3$ & 22 \\
\hline & $\mathrm{O} 1$ & $11.3 \pm 1.2$ & $9.7 \pm 0.3$ & 86 & $110 \pm 3$ & 1 & $45 \pm 8$ & 0.4 & $1.5 \pm 0.2$ & 13 \\
\hline & $\mathrm{O} 2$ & $15.6 \pm 0.9$ & $11.2 \pm 0.4$ & 72 & $303 \pm 8$ & 2 & $38 \pm 7$ & 0.2 & $4.1 \pm 0.2$ & 26 \\
\hline & $\mathrm{O} 3$ & $17.3 \pm 0.9$ & $11.2 \pm 0.03$ & 65 & $380 \pm 10$ & 2 & $218 \pm 19$ & 1 & $5.5 \pm 0.3$ & 32 \\
\hline & W1 & $13.7 \pm 2.4$ & $8.0 \pm 0.6$ & 58 & $1670 \pm 46$ & 12 & $772 \pm 55$ & 6 & $3.2 \pm 0.6$ & 24 \\
\hline & W2 & $12.7 \pm 1.5$ & $7.3 \pm 0.4$ & 57 & $1243 \pm 32$ & 10 & $842 \pm 60$ & 7 & $3.4 \pm 0.4$ & 26 \\
\hline & W3 & $6.4 \pm 1.4$ & $4.3 \pm 0.8$ & 67 & $309 \pm 10$ & 5 & n.d. & & n.d. & \\
\hline & HH1 & $7.6 \pm 0.8$ & $5.7 \pm 0.2$ & 75 & $643 \pm 26$ & 8 & $100 \pm 12$ & 1 & $1.1 \pm 0.1$ & 15 \\
\hline & $\mathrm{HH} 2$ & $6.0 \pm 0.5$ & $5.1 \pm 0.2$ & 85 & $574 \pm 24$ & 10 & $88 \pm 9$ & 1 & $0.23 \pm 0.02$ & 4 \\
\hline \multirow[t]{6}{*}{ Boiler Ash } & $\mathrm{O} 1$ & $6.5 \pm 0.9$ & $6.1 \pm 0.2$ & 93 & $18 \pm 0.4$ & 0.3 & $4.7 \pm 0.6$ & 0.1 & $0.40 \pm 0.06$ & 6 \\
\hline & $\mathrm{O} 2$ & $9.5 \pm 0.5$ & $8.1 \pm 0.1$ & 86 & $18 \pm 0.4$ & 0.2 & $3.8 \pm 0.7$ & 0.04 & $1.3 \pm 0.1$ & 14 \\
\hline & W1 & $23.9 \pm 1.6$ & $21.7 \pm 0.2$ & 91 & $23 \pm 0.5$ & 0.1 & $16 \pm 3.2$ & 0.1 & $2.1 \pm 0.1$ & 9 \\
\hline & W2 & $39.6 \pm 8.3$ & $36.2 \pm 0.3$ & 91 & $18 \pm 0.4$ & 0.05 & $3.6 \pm 1.5$ & 0.01 & $3.4 \pm 0.7$ & 9 \\
\hline & HH1 & $16.3 \pm 3.8$ & $14.2 \pm 0.8$ & 87 & $46 \pm 1.2$ & 0.3 & $3.4 \pm 0.6$ & 0.02 & $2.0 \pm 0.5$ & 13 \\
\hline & $\mathrm{HH} 2$ & $10.3 \pm 3.8$ & $9.2 \pm 0.4$ & 90 & $30 \pm 0.9$ & 0.3 & $7.3 \pm 1.6$ & 0.1 & $1.0 \pm 0.4$ & 10 \\
\hline \multirow[t]{9}{*}{ EPD } & $\mathrm{H} 1$ & $10.3 \pm 0.4$ & $9.3 \pm 0.5$ & 90 & $49 \pm 1.4$ & 0.5 & $16 \pm 9.4$ & 0.2 & $0.93 \pm 0.04$ & 9 \\
\hline & $\mathrm{H} 2$ & $20.2 \pm 0.3$ & $18.8 \pm 0.5$ & 93 & $59 \pm 1.6$ & 0.3 & $21 \pm 9.5$ & 0.1 & $1.3 \pm 0.2$ & 7 \\
\hline & $\mathrm{H} 3$ & $25.7 \pm 0.1$ & $24.4 \pm 0.4$ & 95 & $42 \pm 1.2$ & 0.2 & $12 \pm 9.5$ & 0.1 & $1.2 \pm 0.1$ & 5 \\
\hline & $\mathrm{O} 1$ & $2.7 \pm 0.5$ & $2.5 \pm 0.02$ & 93 & $11 \pm 0.3$ & 0.4 & $46 \pm 8.5$ & 1.7 & $0.14 \pm 0.03$ & 5 \\
\hline & $\mathrm{O} 2$ & $3.3 \pm 0.4$ & $3.0 \pm 0.2$ & 90 & $14 \pm 0.3$ & 0.4 & $34 \pm 6.9$ & 1.0 & $0.27 \pm 0.03$ & 8 \\
\hline & W1 & $6.3 \pm 1.2$ & $5.6 \pm 0.2$ & 89 & $14 \pm 0.3$ & 0.2 & $14 \pm 4.2$ & 0.2 & $0.63 \pm 0.12$ & 10 \\
\hline & W2 & $5.5 \pm 0.6$ & $4.9 \pm 0.2$ & 89 & $13 \pm 0.3$ & 0.2 & $22 \pm 6.3$ & 0.4 & $0.55 \pm 0.06$ & 10 \\
\hline & HH1 & $4.6 \pm 0.6$ & $4.3 \pm 0.4$ & 94 & $33 \pm 1.0$ & 0.7 & $20 \pm 2.6$ & 0.4 & $0.23 \pm 0.03$ & 5 \\
\hline & HH2 & $3.7 \pm 1.0$ & $3.3 \pm 0.1$ & 89 & $32 \pm 1.0$ & 0.9 & $28 \pm 3.9$ & 0.7 & $0.36 \pm 0.10$ & 10 \\
\hline
\end{tabular}

EPD, electrostatic precipitator dust; TOC, total organic carbon; EC, elemental carbon; $\mathrm{EOC}_{2} \mathrm{H}_{2} \mathrm{O}$, water extractable organic carbon, $\mathrm{EOC}^{\mathrm{CH}_{2} \mathrm{Cl}_{2}}$, Dichloromethane extractable organic carbon; NEOC, non extractable organic carbon; DM, dry matter; n.d., not determined.

a Percentage of TOC. 
gen and using ceric (IV) oxide as a catalysts. The oxidized gases are led to a non-dispersive infrared detector. Details about the equipment are described elsewhere [6]. The principle of analysis is based on the higher thermal and chemical stability of EC relative to OC $[16,18,19]$. The appropriate temperature which enables to distinguish between organic and EC has been investigated for each solid residue individually by thermogravimetric analysis. Calibration of peak areas was accomplished by combustion or pyrolysis of sulfanilic acid (bottom ash and boiler ash) and benzoic acid (EPD) respectively. Reference compounds were mixed with quartz sand corresponding to the desired concentration. Accuracy and recovery of the pyrolysis and combustion equipment were determined by analyzing mixtures containing industrial soots with known EC content and different organic substances, respectively [6].

\subsection{Sequential extraction and quantitative determination of extraction yield}

In order to quantify water extractable and dichloromethane extractable organic carbon the solid residues were subjected to a sequential extraction procedure followed by quantitative determination of the extraction yield. First three sequential extractions with Nanopur water at $\mathrm{pH} 12,7$ and 2 were accomplished. Extractions were performed in an ultrasonic bath for $30 \mathrm{~min}$ each. The yield of the water extractions was quantified by determining the DOC content of the extraction solutions which previously have been diluted to a definite volume. Following the water extractions, the dried samples were sequentially extracted with dichloromethane in a soxhlet equipment during $24 \mathrm{~h}$. After completely removing the solvent from the extract, the yield was quantified by determining the weight and the carbon content of the extraction residue.

\subsection{Fourier transform infrared spectroscopy}

The characterization of functional groups in water and organic extracts (Fig. 1) was carried out using a FTIR spectrometer (BioRad FTS 45). Dichloromethane extracts were reduced to a few milliliters and applied directly to the measuring element. After complete evaporation of the solvent absorption spectra in the range of $700-4000 \mathrm{~cm}^{-1}$ were recorded, carrying out 256 scans for each spectrum. A direct investigation of the water extracts was not possible due to strong interferences caused by inorganic salts such as sulphate or nitrate. In

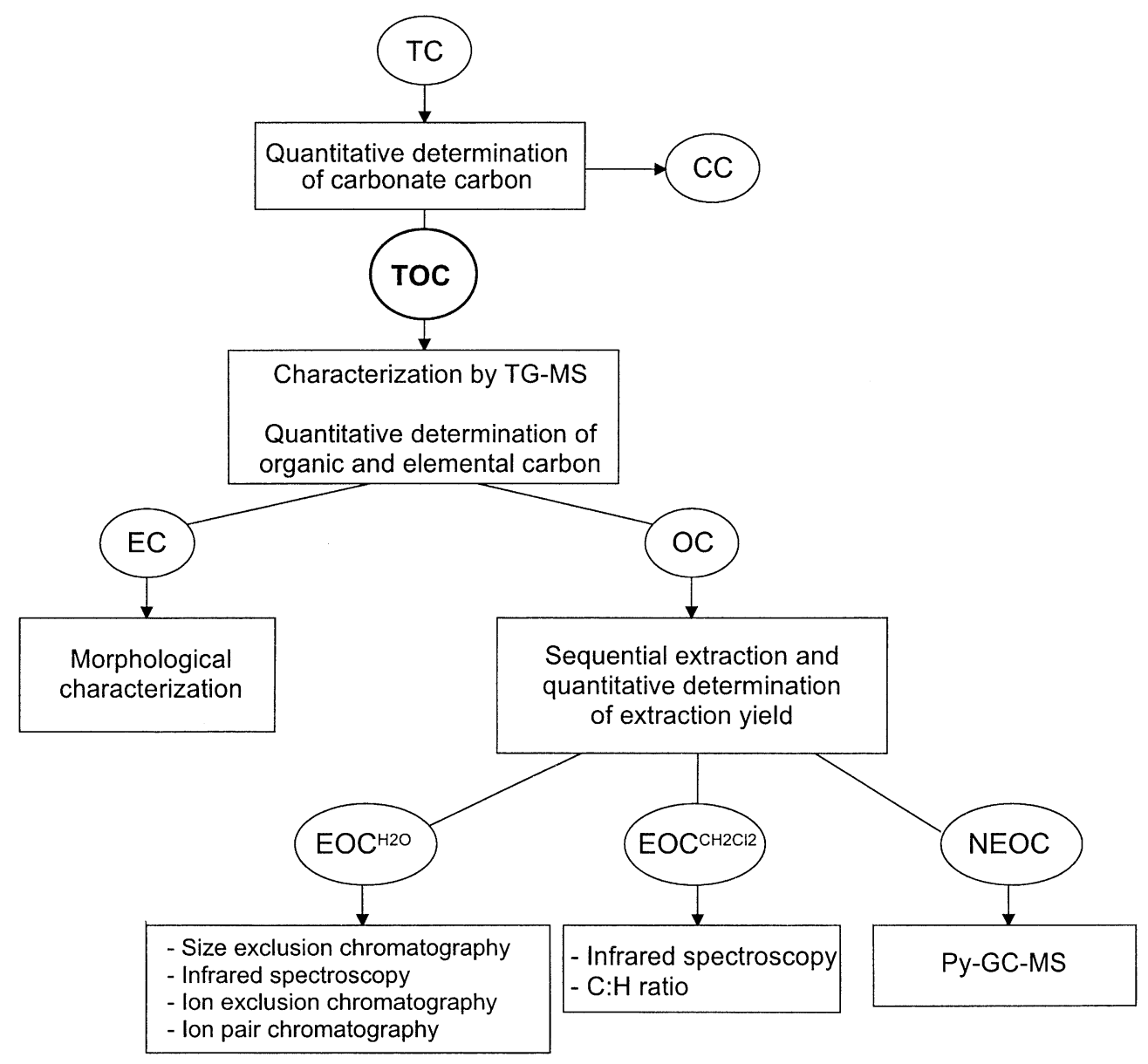

Fig. 1. Analytical procedure for the chemical characterization of carbon species. 
this case, a transfer of organic compounds from the water into an organic phase was carried out using diethyl ether as solvent. For FTIR measurements the same analytical parameters are used as with dichloromethane extracts.

\subsection{Size exclusion chromatography}

The molecular weight distribution in water extracts was determined using a size exclusion column (Pharmacia Superdex Peptide HR 10/30) which is designed to separate molecular weights between 100 and 10,000 amu. The eluent, a $10^{-2} \mathrm{M}$ phosphate buffer solution $(\mathrm{pH}=7)$, was transported by a pump throughout the column and subsequently on-line into a DOC analyzer (Maihek TOCOR 2). Sample preparation was carried out following a procedure that has been developed for the determination of molecular weight distributions in lake waters [6,20]. One hundred and fifty $\mu 13 \mathrm{M} \mathrm{HCl}$ (for alkaline extract) or $20 \mu 13 \mathrm{M} \mathrm{HCl}$ (for neutral extract) is added to $10 \mathrm{ml}$ of the aqueous extract and gently purged with nitrogen during $5 \mathrm{~min}$ to remove dissolved carbonic acid. The $\mathrm{pH}$ value is adjusted to about seven with $3 \mathrm{M} \mathrm{NaOH}$ and a few milligrams of phosphate buffer $\left(\mathrm{Na}_{2} \mathrm{HPO}_{4}\right.$ and $\mathrm{KH}_{2} \mathrm{PO}_{4}$ in mol ratio 1:1) is added. Subsequently, the solution is filtered through a $0.45 \mu \mathrm{m}$ membrane filter and samples are stored in sealed vials under nitrogen to prevent any access of $\mathrm{CO}_{2}$. In order to calibrate the column, retention times of the reference compounds Glycine (MW 75), Dextran 1000 (MW 1000) and Dextran 20 (MW 20,000) were determined.

\subsection{Ion exclusion and ion-pair liquid chromatography}

Quantitative determination of lactic, formic, acetic, oxalic and maleic acid was performed using a HPLC system (Sykam) equipped with an ion exclusion column (Grom Acid 1, $5 \mu \mathrm{m}, 300 \times 7.8 \mathrm{~mm}$ i.d.) and a UV detector (Linear 205). Quantitative determination of terephthalic, phthalic and benzoic acid was performed using a HPLC system (Hewlett Packard 1090L) equipped with an ion pair column (Hypersil ODS, $5 \mu \mathrm{m}$, $250 \times 4 \mathrm{~mm}$ i.d.) and a UV diode array detector. Details are described elsewhere $[6,21,22]$.

\subsection{Pyrolysis-gas chromatography-mass spectrometry}

Qualitative characterization of NEOC was achieved using a GC-MS system (GC Hewlett Packard 5890 II; MS Hewlett Packard 5989A) equipped with a filament pyrolyzer (CDS Pyroprobe 2000). Pyrolysis products emitted to the gas phase were separated in a DB5 column (30 m; $0.53 \mathrm{~mm}$ I.D.; $5 \mu \mathrm{m})$ coupled with a HP5 column $(1 \mathrm{~m} ; 0.2 \mathrm{~mm}$ I.D.; $0.33 \mu \mathrm{m})$. Samples were pyrolyzed in a quartz boat at a temperature of $600{ }^{\circ} \mathrm{C}$. Due to the relatively low capacity of the quartz boat (about $30 \mathrm{mg}$ ), an enrichment of NEOC in bottom ash samples by density separation has been carried out [6].

\subsection{Optical and scanning electron microscopy}

Soot particles in boiler ash and electrostatic precipitator dust samples were investigated by scanning electron microscopy (SEM) (Leitz AMR 1000). Secondary micrographs were taken at a voltage of $20 \mathrm{kV}$. Because soot particles are good electrical conductors, no coating is required. Quantitative classification of soot particles according to the corresponding precursors was performed with an optical microscope (Wild M8).

\section{Results and discussion}

\subsection{Thermogravimetric characterization of carbon species}

Fig. 2a shows the thermogravimmetric analysis of the bottom ash sample $\mathrm{H} 1$ from the MSW incinerator of Hinwil under oxidizing atmosphere. Qualitatively, the other investigated bottom ash samples showed very similar results. The upper curve in the thermogram displays the sample weight plotted as a function of temperature. The weight scale indicated on the right y-axis represents $10 \%$ of the whole sample weight. The two lower curves display the relative intensities of water and carbon dioxide detected by mass spectrometry.

The $\mathrm{CO}_{2}$ curve in Fig. 2 a shows three distinct peaks which can be assigned to three different carbon species. The first peak beginning at $210{ }^{\circ} \mathrm{C}$ and reaching the maximum at $315^{\circ} \mathrm{C}$ is the oxidation of $\mathrm{OC}$. The second, clearly higher peak with a maximum at $470{ }^{\circ} \mathrm{C}$ is the oxidation of EC or soot and the third peak of the $\mathrm{CO}_{2}$ curve with a maximum at $710{ }^{\circ} \mathrm{C}$ is caused by the thermal decomposition of carbonates. In the range of the third $\mathrm{CO}_{2}$ peak the sample weight decreases by $1.7 \%$. The carbonate carbon content determined coulometrically amounts to $0.43 \%$ relative to carbon and $1.6 \%$ relative to $\mathrm{CO}_{2}$. Therefore, the weight loss between 620 and $750{ }^{\circ} \mathrm{C}$ can be attributed almost completely to the decomposition of carbonates.

The assignment of the three peaks in the $\mathrm{CO}_{2}$ curve to organic, elemental and carbonate carbon is confirmed by the course of the $\mathrm{H}_{2} \mathrm{O}$ curve (Fig. 2a). The first peak with a maximum at approximately $100{ }^{\circ} \mathrm{C}$ corresponds to the loss of adsorbed or crystal water. From 210 $620{ }^{\circ} \mathrm{C}$ the $\mathrm{H}_{2} \mathrm{O}$ curve proceeds parallel to the $\mathrm{CO}_{2}$ curve. The second peak with a maximum at $315{ }^{\circ} \mathrm{C}$ is caused by the oxidation of organic compounds. Because soot consists not only of elemental carbon but always contains other elements like hydrogen [16], a small but clear $\mathrm{H}_{2} \mathrm{O}$ peak is observed at $470{ }^{\circ} \mathrm{C}$. However, no rising of the $\mathrm{H}_{2} \mathrm{O}$ curve is detected during the thermal decomposition of carbonates as expected. 

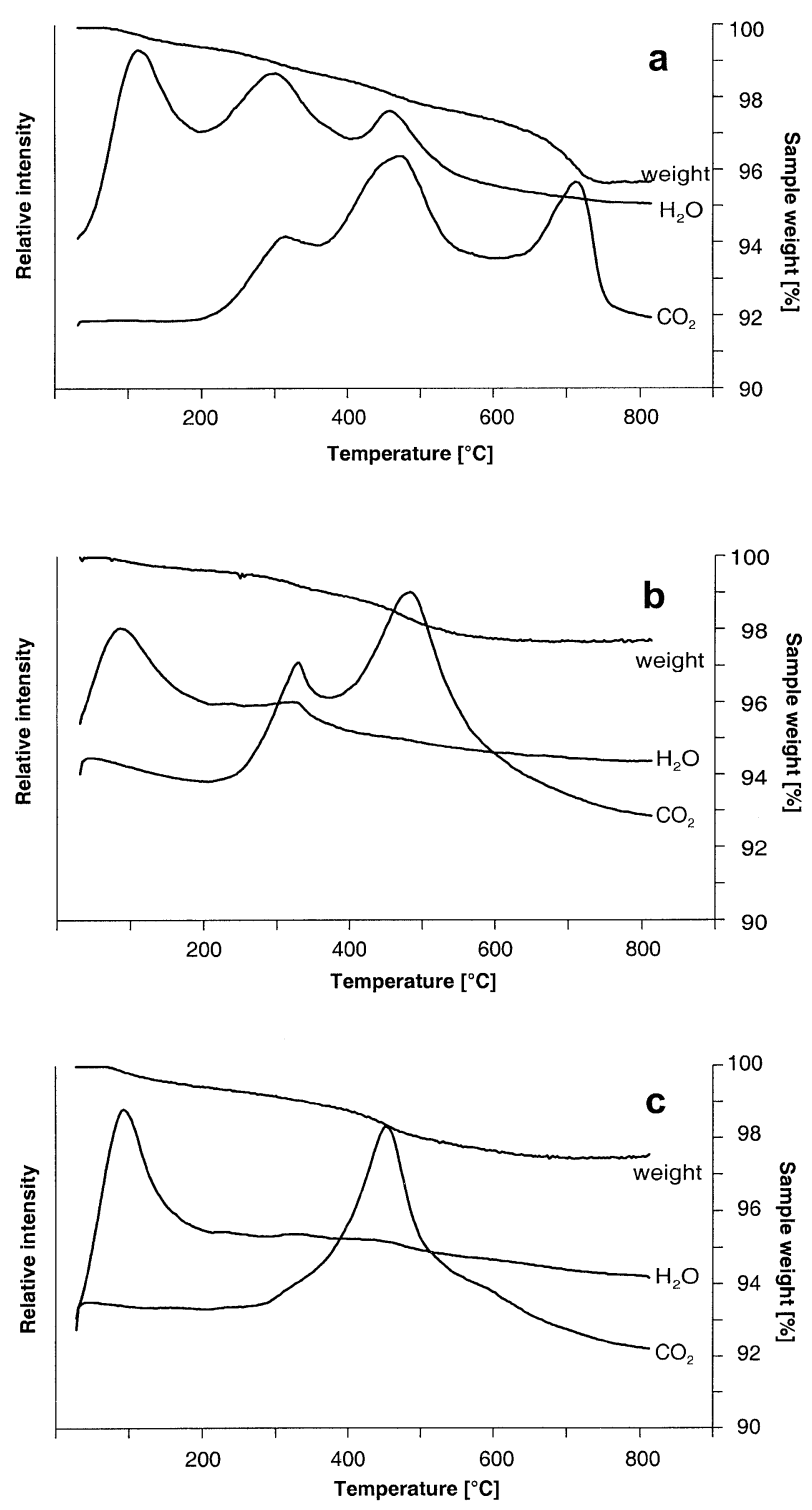

Fig. 2. Thermogravity-mass spectrometry (TG-MS) analysis of bottom ash sample $\mathrm{H} 1$ untreated (a), treated with diluted $\mathrm{HCl}$ (b) and treated with $6 \mathrm{M} \mathrm{HNO}_{3}$ (c) under oxidizing atmosphere.

A further possibility for the identification of $\mathrm{CO}_{2}$ peaks consists in removing selectively a certain carbon species by treating the sample appropriately and reanalyzing the treated sample under identical analytical conditions. The third $\mathrm{CO}_{2}$ peak for example, can be identified as carbonate carbon by acidifying the bottom ash sample with diluted hydrochloric acid. In the thermogram of the analysis performed after sample treatment a complete loss of the third peak is observed (Fig. 2b). The identification of the first and second $\mathrm{CO}_{2}$ peak is accomplished by a similar procedure. Treating bottom ash samples with $6 \mathrm{M} \mathrm{HNO}_{3}$ and boiling under reflux during $2 \mathrm{~h}$ causes a complete oxidation of organic carbon while elemental carbon is affected only partially due to its inert chemical properties (Fig. 2c). Carbonates are also removed by this treatment.

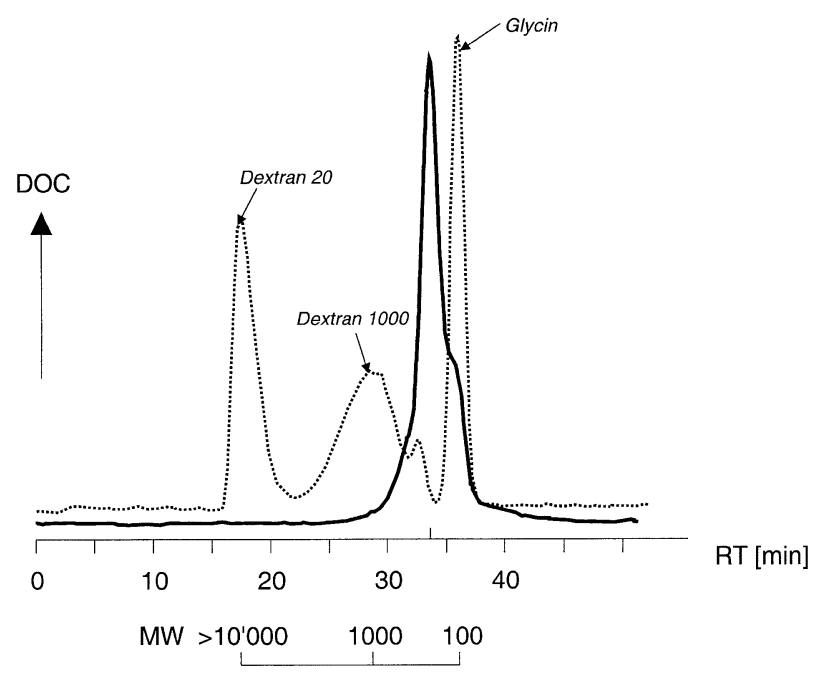

Fig. 3. Molecular weight distribution in alkaline extract of bottom ash sample H2. Dotted line: Calibration curve.

The temperature at which oxidation of EC occurs in bottom ash samples is surprisingly low considering the well known thermal stability of this carbon species [16]. Investigating pure flame soot under identical analytical conditions the oxidation of EC occurs between 600 and $740{ }^{\circ} \mathrm{C}$ with a maximum at $660{ }^{\circ} \mathrm{C}$ [6]. When the same industrial soot is mixed with a sample of bottom ash which was glowed at $900{ }^{\circ} \mathrm{C}$ in order to remove any carbon and analyzed as before, the temperature of EC oxidation is lowered by 150 to $510{ }^{\circ} \mathrm{C}$. In the case of furnace and gas soot the difference amounts to even 170 and $220^{\circ} \mathrm{C}$, respectively [6]. A possible explanation for this observation are catalytic effects caused by metals or metal oxides present in bottom ash [23].

\subsection{Contents of carbon species}

The concentrations of carbon species $\mathrm{EC}, \mathrm{EOC}^{\mathrm{H}_{2} \mathrm{O}}$, EOC $\mathrm{CH}_{2} \mathrm{Cl}_{2}$ and NEOC as well as their relative contributions to TOC of bottom ash samples are listed in Table 2. For all investigated bottom ash samples EC represents quantitatively the most important carbon species. Its percentage relative to TOC ranges between $57 \%$ (sample W2) and 86\% (sample O1). The majority of OC cannot be extracted with water or dichloromethane as effluents. Therefore NEOC represents the second most important carbon species after EC (excepting sample $\mathrm{HH} 2$ ). Water turns out to obtain a higher extraction yield compared with dichloromethane for all bottom ash samples. Therefore extractable organic carbon shows a mostly polar character.

Comparing bottom ash samples of the four investigated MSW incinerators significant differences in TOC composition can be identified. The samples from Hagenholz show the lowest TOC contents and at the same time the smallest percentages of OC relative to TOC. In contrast, TOC of bottom ashes from Winterthur and Hinwil 
Table 3

Concentrations of aliphatic and aromatic acids in bottom ash samples

\begin{tabular}{|c|c|c|c|c|c|c|c|c|}
\hline \multirow[t]{2}{*}{ Sample } & Lactic acid & Formic acid & Acetic acid & Oxalic acid & Maleic acid & Terephtalic acid & Phtalic acid & Benzoic acid \\
\hline & $\left(\mathrm{mg} \mathrm{kg}^{-1} \mathrm{DM}\right)$ & $\left(\mathrm{mg} \mathrm{kg}^{-1} \mathrm{DM}\right)$ & $\left(\mathrm{mg} \mathrm{kg}^{-1} \mathrm{DM}\right)$ & $\left(\mathrm{mg} \mathrm{kg}^{-1} \mathrm{DM}\right)$ & $\left(\mathrm{mg} \mathrm{kg}^{-1} \mathrm{DM}\right)$ & $\left(\mathrm{mg} \mathrm{kg}^{-1} \mathrm{DM}\right)$ & $\left(\mathrm{mg} \mathrm{kg}^{-1} \mathrm{DM}\right)$ & $\left(\mathrm{mg} \mathrm{kg}^{-1} \mathrm{DM}\right)$ \\
\hline H1 & $170 \pm 5.5$ & $86 \pm 1.4$ & $77 \pm 1.8$ & $19 \pm 0.5$ & $0.35 \pm 0.03$ & $5.8 \pm 0.3$ & $1.6 \pm 0.04$ & $2.8 \pm 0.1$ \\
\hline $\mathrm{H} 2$ & $172 \pm 3.0$ & $73 \pm 0.9$ & $77 \pm 1.6$ & $21 \pm 0.9$ & $0.66 \pm 0.08$ & $5.2 \pm 0.06$ & $1.5 \pm 0.03$ & $2.3 \pm 0.03$ \\
\hline H3 & $171 \pm 5.8$ & $74 \pm 1.5$ & $86 \pm 4.2$ & $19 \pm 1.1$ & $0.83 \pm 0.03$ & $8.1 \pm 0.2$ & $3.8 \pm 0.2$ & $3.4 \pm 0.1$ \\
\hline $\mathrm{O} 1$ & $4.9 \pm 0.8$ & $14 \pm 1.6$ & $11 \pm 1.6$ & $2.6 \pm 1.9$ & n.d & $0.19 \pm 0.01$ & $0.97 \pm 0.03$ & $0.65 \pm 0.02$ \\
\hline $\mathrm{O} 2$ & n.d. & $17 \pm 2.5$ & $84 \pm 9.2$ & $5.2 \pm 2.4$ & n.d & $1.4 \pm 0.1$ & $0.54 \pm 0.05$ & $1.0 \pm 0.08$ \\
\hline $\mathrm{O} 3$ & $11 \pm 2.2$ & $34 \pm 2.2$ & $42 \pm 1.0$ & $8.8 \pm 1.1$ & n.d & $1.3 \pm 0.08$ & $0.74 \pm 0.1$ & $0.68 \pm 0.02$ \\
\hline W1 & $51 \pm 1.4$ & $66 \pm 1.2$ & $101 \pm 2.9$ & $20 \pm 2.2$ & $0.40 \pm 0.03$ & $14.3 \pm 0.06$ & $3.5 \pm 0.05$ & $5.5 \pm 0.08$ \\
\hline W2 & $54 \pm 0.5$ & $35 \pm 0.9$ & $93 \pm 4.8$ & $13 \pm 0.3$ & $0.16 \pm 0.04$ & $7.5 \pm 0.2$ & $1.9 \pm 0.06$ & $3.8 \pm 0.2$ \\
\hline W3 & $12 \pm 1.9$ & $12 \pm 0.4$ & $25 \pm 3.3$ & $4.4 \pm 1.1$ & $0.05 \pm 0.03$ & $9.5 \pm 0.1$ & $1.5 \pm 0.1$ & $4.0 \pm 0.06$ \\
\hline HH1 & $59 \pm 3.1$ & $15 \pm 0.9$ & $33 \pm 1.3$ & $3.6 \pm 0.2$ & n.d. & $0.81 \pm 0.04$ & $0.85 \pm 0.05$ & $17.1 \pm 0.2$ \\
\hline HH2 & $63 \pm 2.3$ & $16 \pm 0.4$ & $31 \pm 4.9$ & $2.2 \pm 0.5$ & n.d. & $0.24 \pm 0.09$ & $1.4 \pm 0.09$ & $16.8 \pm 0.4$ \\
\hline
\end{tabular}

n.d., not detectable; DM, dry matter.

operated with the same grate type (Table 1) show similar TOC compositions with significant higher percentages of OC. Bottom ash samples from Oftringen show a different characteristic behavior. Although TOC contents of these samples are relatively high the percentages of $\mathrm{EOC}^{\mathrm{H}_{2} \mathrm{O}}$ and $\mathrm{EOC}^{\mathrm{CH}_{2} \mathrm{Cl}_{2}}$ are significant lower compared with other incinerators.

Electrostatic precipitator dust and boiler ash show no significant differences in TOC composition. EC is the dominant carbon species in both the solid residues. The mean percentage of EC relative to TOC amounts to 90\% (boiler ash) and 91\% (electrostatic precipitator dust). The majority of OC cannot be extracted with water or dichloromethane (Table 2). Therefore, NEOC is the second most important carbon species after EC.

\subsection{Characterization of $E O C^{\mathrm{H}_{2} \mathrm{O}}, E O C^{\mathrm{CH}_{2} \mathrm{Cl}_{2}}$ and NEOC in bottom ash samples}

Determination of the molecular weight distribution in alkaline extracts from the extraction of bottom ash with water at $\mathrm{pH} 12$ enables a first qualitative survey of $\mathrm{EOC}^{\mathrm{H}_{2} \mathrm{O}}$ (Fig. 3). In the chromatogram of bottom ash sample $\mathrm{H} 2$ only one signal with a maximum at $33 \mathrm{~min}$ is detected. Based on a comparison with reference compounds (dotted line in Fig. 3) no molecular weights $>1000 \mathrm{amu}$ are detected. DOC of alkaline extracts therefore consists completely of low molecular weight compounds. Alkaline extracts of 10 years old bottom ashes deposited in monofills show interesting differences to fresh samples concerning the molecular weight distribution. In deposited bottom ash samples apart of low molecular weight compounds also substances with molecular weights between 1000 and $10,000 \mathrm{amu}$ are detected [7]. A possible explanation for this difference is the formation of high molecular weight organic compounds by microbial degradation processes during deposition in monofills. This hypothesis is confirmed by laboratory experiments showing that a partial microbial degradation of DOC in alkaline extracts occurs under the conditions investigated [7].

Infrared spectroscopy supplies further indications about the composition of $\mathrm{EOC}^{\mathrm{H}_{2} \mathrm{O}}$ (Fig. 4). The $\mathrm{C}-\mathrm{H}$ stretching bonds detected between 3000 and $2800 \mathrm{~cm}^{-1}$ point to a high content of aliphatic compounds in alkaline extracts. However, the missing of aromatic $\mathrm{C}-\mathrm{H}$ stretching bonds between 3200 and $3000 \mathrm{~cm}^{-1}$ cannot be interpreted with a complete absence of aromatic compounds due to their low intensity. At $1700 \mathrm{~cm}^{-1}$ the FTIR spectrum shows a strong absorption band which can be assigned to $\mathrm{C}=\mathrm{O}$ stretching bonds. This absorption band shows a strong $\mathrm{pH}$ dependence pointing to a high occurrence of carboxylic groups. In the range between 1600 and $750 \mathrm{~cm}^{-1}$ further absorptions with partly very sharp character are detected. However, these bands cannot be assigned clearly to individual functional groups because different interpretation possibilities exist. Alkyl, alkenyl, hydroxyl, ether and ester as well as nitro and halogen groups are possible explanations.

In all investigated bottom ash samples low molecular weight and very polar organic acids have been detected by chromatography. Aliphatic acids (lactic, formic, acetic, oxalic and maleic acid) as well as aromatic acids (benzoic, phtalic and terephtalic acid) have been found. Corresponding concentrations are listed in Table 3. The contents of aliphatic acids are approximately one order of magnitude higher compared with aromatic acids. The four incinerators investigated show significant differences in aliphatic and aromatic acid contents of bottom ashes. The concentrations in samples from Oftringen for example, are significantly lower although TOC contents of these samples are increased compared with the samples of the other incinerators. Low molecular weight and very polar organic acids are well known products of thermal decomposition of organic materials like cellulose or lignin [24-26]. Their occurrence in bottom ashes can be explained by pyrolytic processes taking place on 


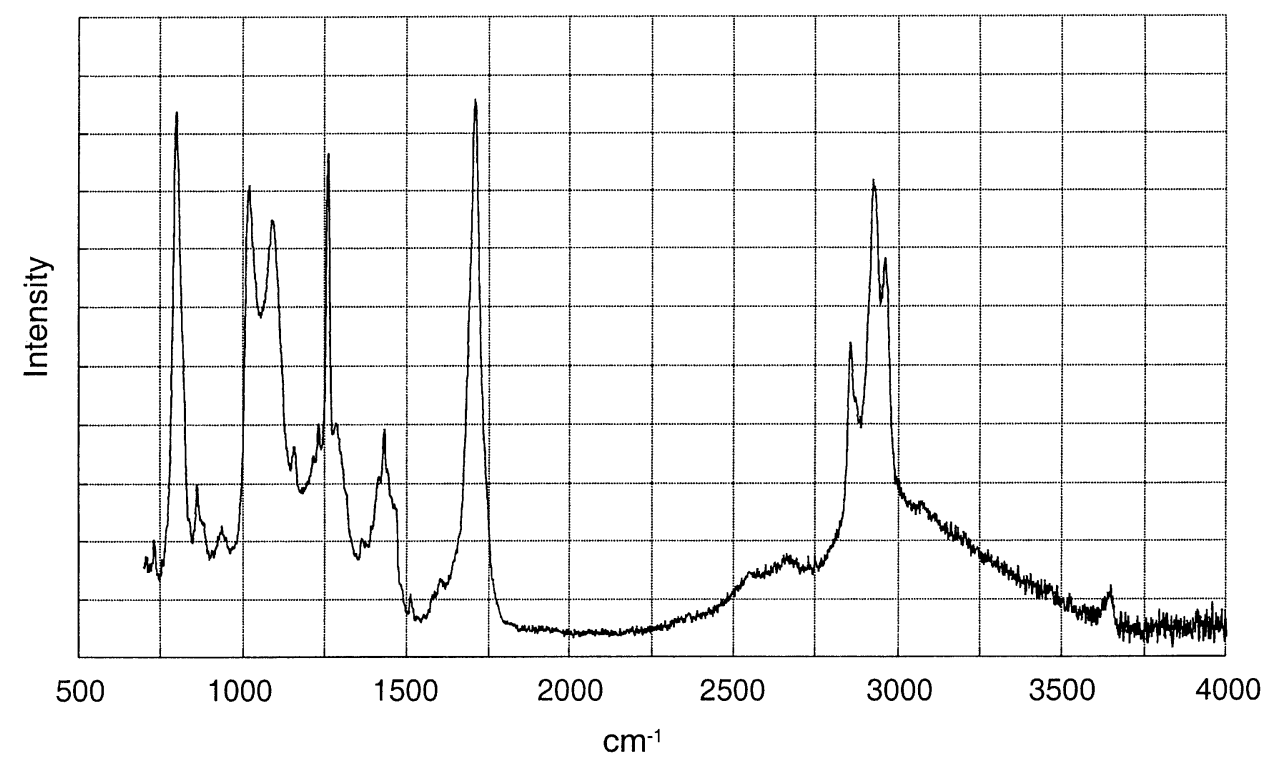

Fig. 4. Fourier transform infrared spectroscopy (FTIR) spectrum of organic compounds isolated from alkaline extracts of bottom ash sample H1 with diethylether.

Table 4

$\mathrm{TC}$ and $\mathrm{TH}$ content and $\mathrm{C}: \mathrm{H}$ ratio in organic extracts of bottom ash samples

\begin{tabular}{llcl}
\hline Sample & TC $(\% \mathrm{w} / \mathrm{w})$ & TH $(\% \mathrm{w} / \mathrm{w})$ & $\mathrm{C} / \mathrm{H}$ \\
\hline H1 & $76 \pm 1.9$ & $11.0 \pm 1.0$ & 0.58 \\
H2 & $79 \pm 1.0$ & $10.9 \pm 0.3$ & 0.61 \\
H3 & $77 \pm 1.0$ & $11.6 \pm 0.7$ & 0.55 \\
O1 & $50 \pm 6.9$ & $5.6 \pm 0.4$ & 0.75 \\
O2 & $49 \pm 6.6$ & $5.3 \pm 0.5$ & 0.78 \\
O3 & $79 \pm 0.6$ & $10.7 \pm 0.3$ & 0.62 \\
W1 & $75 \pm 0.5$ & $9.1 \pm 0.9$ & 0.69 \\
W2 & $79 \pm 3.3$ & $11.5 \pm 1.0$ & 0.58 \\
HH1 & $65 \pm 4.2$ & $6.9 \pm 0.6$ & 0.79 \\
HH2 & $51 \pm 8.8$ & $4.5 \pm 0.8$ & 0.95 \\
\hline
\end{tabular}

the furnace grate [6]. The bottom ash sample W3 which was sampled before the quench tank also contains aliphatic and aromatic acids as well. For that reason it can be excluded that the polar acids are only formed in the quench tank.

$\mathrm{TC}$ and $\mathrm{TH}$ contents as well as the $\mathrm{C}: \mathrm{H}$ ratio in organic extracts are listed in Table 4 . In the case of bottom ash samples $\mathrm{H} 1-\mathrm{H} 3, \mathrm{O} 3, \mathrm{~W} 1$ and $\mathrm{W} 2$ the organic extracts are composed to about $90 \%$ by weight of these two elements. Therefore, it can be concluded that organic extracts of these samples consist mainly of apolar hydrocarbons having few functional groups with hetero atoms like oxygen or nitrogen. The mean $\mathrm{C}: \mathrm{H}$ ratio of bottom ash samples amounts to 0.69. Considering the $\mathrm{C}: \mathrm{H}$ ratio of organic compounds like aliphatic hydrocarbons (e.g. $\mathrm{C}_{18} \mathrm{H}_{38}: 0.47$ ), polyethylene $(0.5)$, cellulose (0.6), benzene (1) or polycyclic aromatic hydrocarbons $(>1)$ this value points to a rather aliphatic character. The first survey given by the $\mathrm{C}: \mathrm{H}$ ratio is confirmed by the characterization with infrared spectroscopy (Fig. 5). Compared with the FTIR spectrum of water extracts (Fig. 4) organic extracts show less intensive absorption bands in the range between 2500 and $700 \mathrm{~cm}^{-1}$ pointing to a less polar character and to a lower occurrence of functional groups. In the range between 3100 and $2800 \mathrm{~cm}^{-1}$ aliphatic as well as aromatic $\mathrm{C}-\mathrm{H}$ stretching bonds are detected. As in the case of water extracts the absorption bands between 2000 and $700 \mathrm{~cm}^{-1}$ cannot be assigned clearly to individual functional groups because different interpretation possibilities exist. Considering the various high concentration compounds identified by Priester et al. [14], it is expected, that these absorptions can be attributed mainly to alkyl, carbonyl and to ester groups.

The results of the pyrolytic investigation of bottom ash sample $\mathrm{H} 3$ with subsequent identification of evolved pyrolysis products by GC-MS are presented in Fig. 6 . The most informative pyrolysis products in the pyrogram of bottom ash sample $\mathrm{H} 3$ providing indications about the NEOC composition are styrene, 2-furancarboxaldehyde, dihydrofuran, 2-oxepanone and pentanone (Table 5). Styrene is formed by the thermal decomposition of polystyrene (PS) [27]. PS belongs to the chemical class of polymers which at heating decomposes mainly to their monomeric components. A further representative of this class of polymers is polymethylmethacrylate (PMMA) [27]. This polymer which decomposes almost quantitatively to methylmethacrylate has been detected in the bottom ash sample $\mathrm{H} 2$. Both 2-furancarboxaldehyde and dihydrofuran are typical products evolved by the thermal decomposition of cellulose [25], while 2-oxepanone originates from polyester and pentanone from polyamide [27]. With an 


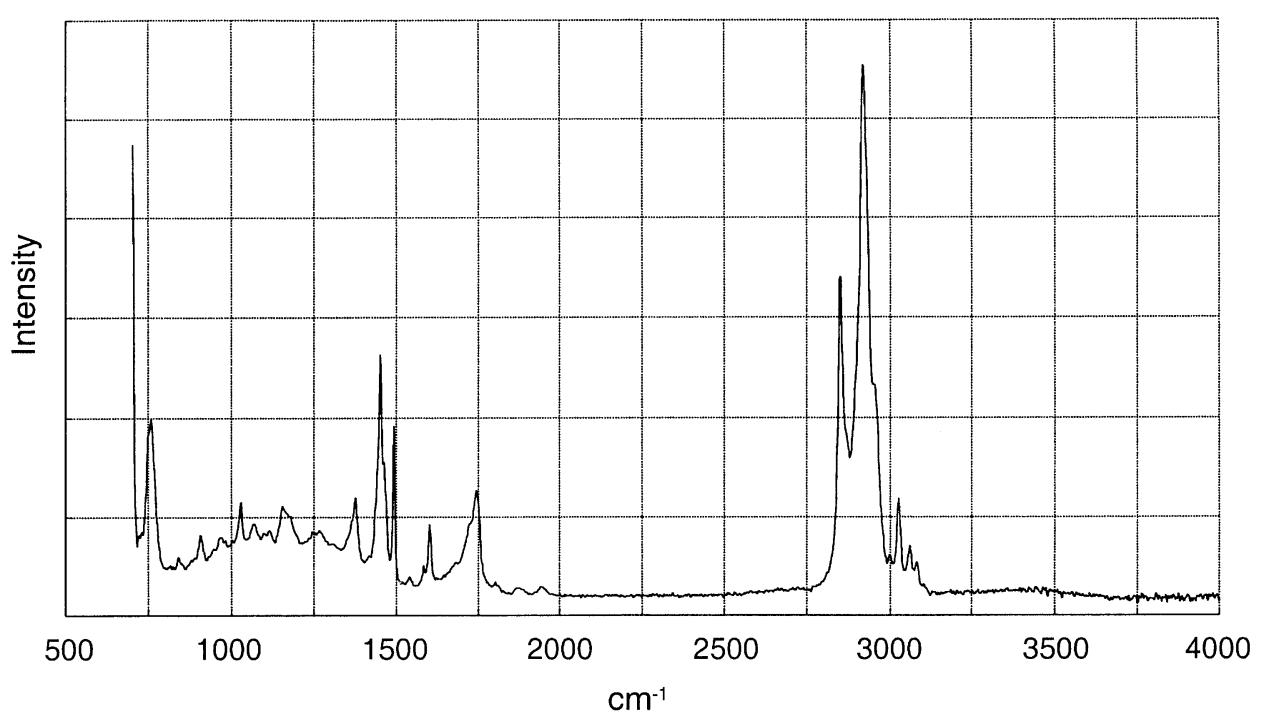

Fig. 5. Fourier transform infrared spectroscopy (FTIR) spectrum of organic extracts of bottom ash sample H2.

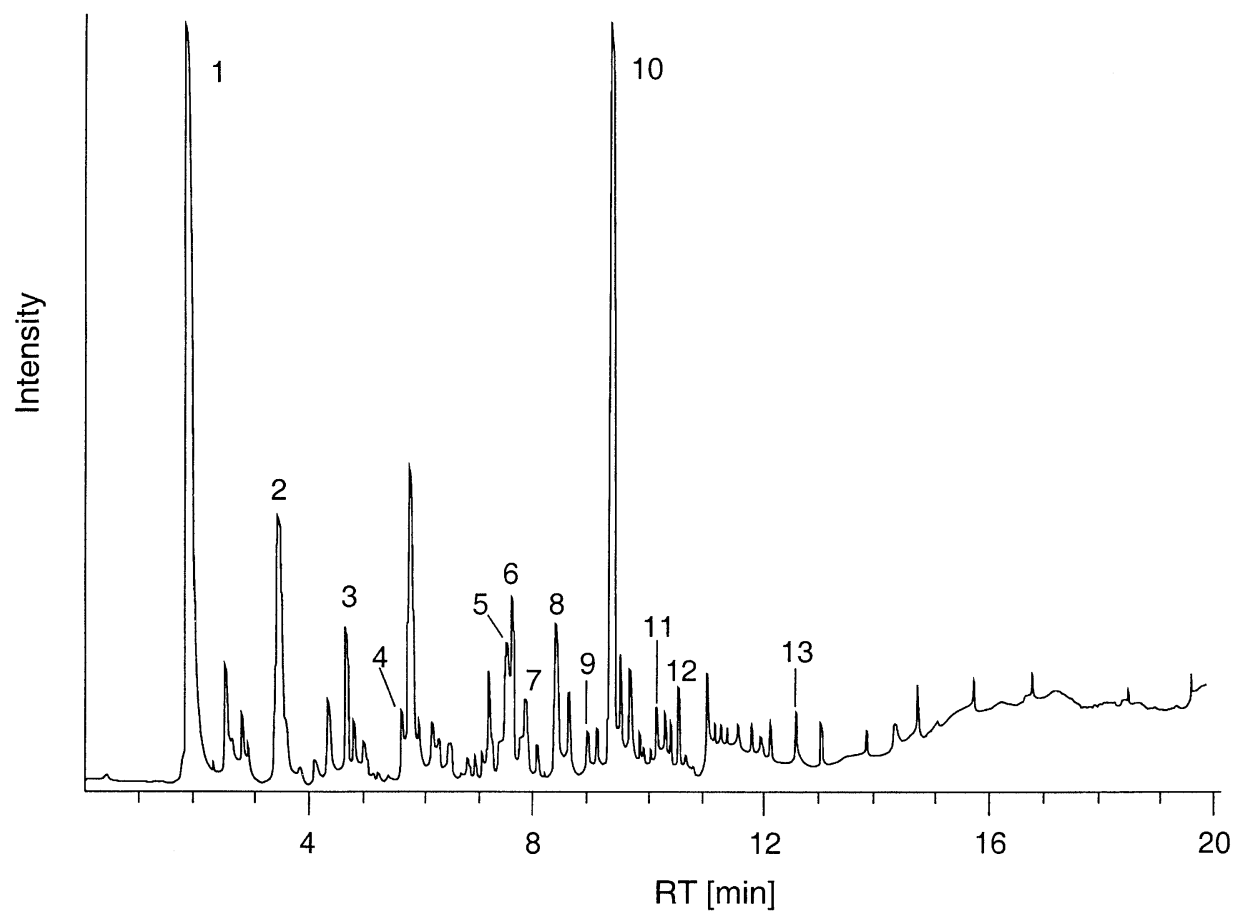

Fig. 6. Pyrogram of the light fraction obtained by density separation of bottom ash sample H3.

estimated content of $33 \%$ by weight [28], cellulose represents by far the most abundant chemical class of organic polymer in MSW. Further pyrolysis products present in the pyrogram shown in Fig. 6 like toluene, xylene or phenol supply no detailed informations about the NEOC composition in bottom ash samples. These products can be formed by thermal decomposition of various organic materials or by secondary reactions of pyrolysis products. Therefore they are not specific and do not enable indications about the NEOC composition.

\subsection{Characterization of EC in boiler ash and electrostatic precipitator dust samples}

Ungrounded boiler ash and electrostatic precipitator dust samples contain black soot particles with grain sizes up to about $10 \mathrm{~mm}$. The morphological investigation of the soot particles provides indications about the formation processes and enables to determine the original organic polymers they are formed from. Fig. 7 shows SEM micrographs of four different soot particles 

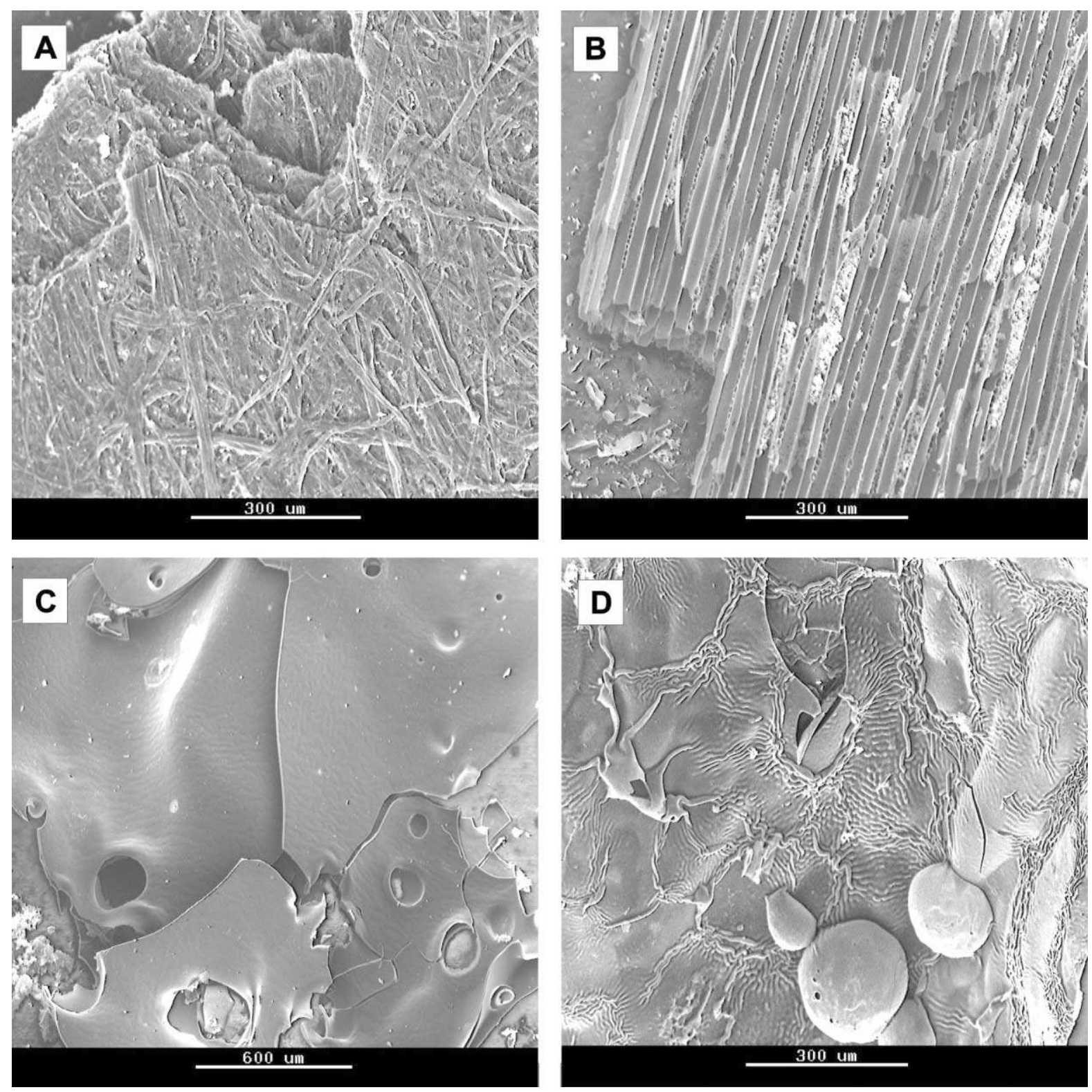

Fig. 7. Scanning electron microscopic pictures of soot particles with different origin at $20 \mathrm{kV}$.

taken by scanning electron microscopy. The SEM micrographs A and B show soot particles of pyrolyzed paper and wood, respectively. The typical fibrous structure of paper and the cellular structure of wood has been preserved during pyrolysis. In contrast to micrographs $\mathrm{A}$ and $\mathrm{B}$, the micrographs $\mathrm{C}$ and $\mathrm{D}$ show soot particles of organic material not identified. Because of the smooth and shiny surface it is supposed that soot particle $\mathrm{C}$ originates from a synthetic polymer. A further criterion for this conclusion are the degassing pores recognizable in Fig. 7C. In order to classify the soot particles quantitatively according to their origin a representative selection from different boiler ash and electrostatic precipitator dust samples were identified by optical microscopy. Based on this investigation about $64 \%$ of the soot particles with grain sizes $>1 \mathrm{~mm}$ can be attributed to pyrolyzed paper and about $28 \%$ to pyrolyzed wood. Other organic materials like those shown in Fig. 7C and D are quantitatively less important.

\section{Conclusions}

The chemical characterization of TOC in MSW incinerator residues can be accomplished by a quantitative classification into $\mathrm{EC}, \mathrm{EOC}^{\mathrm{H}_{2} \mathrm{O}}, \mathrm{EOC}^{\mathrm{CH}_{2} \mathrm{Cl}_{2}}$ and NEOC and by following chemical and morphological investigation of individual carbon species. Bottom ash, boiler ash and air pollution control residues show significant differences in TOC composition and in contents of individual carbon species. While TOC of boiler ash and air pollution control residues is mainly dominated 
Table 5

Pyrolysis products identified in the pyrogram of bottom ash sample H3 (Fig. 6)

\begin{tabular}{ccll}
\hline Peak & RT (min) & Compound & Original polymer \\
\hline 1 & 1.9 & $\mathrm{CO}_{2}$ & \\
2 & 3.5 & Acetone & \\
3 & 4.7 & Pentanone & (Polyamide) \\
4 & 5.7 & Dihydrofuran & Cellulose \\
5 & 7.5 & Hexanone & \\
6 & 7.6 & Toluene & \\
7 & 7.8 & Piperidine & Cellulose \\
8 & 8.4 & 2-Furancarboxaldehyde & \\
9 & 9.1 & Xylene & Polystyrene \\
10 & 9.4 & Styrene & \\
11 & 10.2 & Phenol & \\
12 & 10.5 & Pyrene or fluoranthene & \\
& & (C) ${ }_{16} \mathrm{H}_{10}$; MW 202) & Polyester \\
13 & 12.6 & 2-Oxepanone & \\
\hline
\end{tabular}

RT, retention time.

by elemental carbon, bottom ash samples show a more manifold and variating TOC composition and a higher percentage of extractable and NEOC.

The results of carbon speciation provide indications concerning the physical and chemical processes occurring in MSW incineration. EC as well as the majority of extractable organic carbon in bottom ashes are formed by the thermal decomposition of organic materials on the furnace grate. NEOC can be attributed in part to organic materials in MSW which are transferred to the bottom ash without being deteriorated chemically. These materials did not reach the critical temperature on the furnace grate necessary for thermal decomposition. They therefore supply indications about the lower temperature range (estimated here as $300-600{ }^{\circ} \mathrm{C}$ ) occurring locally in the furnace bed. In the case of boiler ashes and air pollution control residues, the most important process leading to high contents of TOC is the whirl up of pyrolyzed organic materials from the furnace bed to the combustion chamber. Cellulose, hemicellulose and lignin (e.g. paper, cardboard, wood or cotton) are most involved in TOC formation in the solid residues investigated in this study. Synthetic polymers like for example, polyethylene or polypropylene are less important. Carbon speciation can be used to optimize mineralization of the solid residues and to carry out a control of combustion operation due to the enhanced comprehension of thermal processes. The four carbon species $\mathrm{EC}, \mathrm{EOC}^{\mathrm{H}_{2} \mathrm{O}}, \mathrm{EOC}^{\mathrm{CH}_{2} \mathrm{Cl}_{2}}$ and $\mathrm{NEOC}$ are more suitable parameters for an estimation of the mineralization of solid residues than TOC.

The potential influence of TOC on the short- and long-term behavior of incinerator residues in landfills can be predicted by considering the content of water extractable organic carbon and of NEOC, respectively. The acid production by microbial degradation of organic carbon is much lower than the acid neutralization capa- city of the bottom ash (compare [4,7,8]). However, it would contribute to the carbonization and to a decrease of the $\mathrm{pH}$ value in a bottom ash landfill. Furthermore, some components of the water extractable organic carbon (e.g. some organic acids) could cause a complexation of some heavy metals and thus their mobilization (compare [9,10]). Consequently, further investigations are needed in the field of the chemical speciation of organic constituents of municipal solid waste incinerator residues and their behavior in landfills.

\section{References}

[1] Baccini P. The landfill - reactor and final storage; lecture notes in earth sciences. Vol. 20. Berlin: Springer-Verlag, 1988.

[2] Baccini P, Belevi H, Lichtensteiger T. Die Deponie in einer ökologisch orientierten Volkswirtschaft (The landfill in an ecologically oriented national economy). GAIA 1992;1:34-49.

[3] Brunner PH, Müller MD, McDow SR, Mönch H. Total organic carbon emissions from municipal incinerators. Waste Management and Research 1987;5:355-65.

[4] Belevi H, Stämpfli DM, Baccini P. Chemical behavior of municipal solid waste incinerator bottom ash in monofills. Waste Management and Research 1992;10:153-67.

[5] Belevi H. Wie wird die Schlacke erzeugt? (How is the bottom ash produced?). In Baccini P., Gamper, B. (eds). Deponierung fester rückstände aus der abfallwirtschaft- endlagerqualität am beispiel der müllschlacke. Verlag der Fachvereine an den schweizerischen Hochschulen und Techniken Zurich. 55-75 vdf Hoschulverlags, Zurich (1994)

[6] Ferrari S. Chemische charakterisierung des kohlenstoffes in rückständen von müllverbrennungsanlagen: methoden und anwendungen (chemical characterization of carbon in incineration residues: methods and applications). PhD thesis no: 12200 . ETH Zürich, Switzerland (1997).

[7] Belevi H, Agustoni-Phan N, Baccini P. Influence of organic carbon on the long-term behavior of bottom ash monofills. In Christensen TH, Cossu R, Stegmann R. (eds). Proceedings of the fourth international landfill symposium. S. Margherita di Pula, Italy (1993).

[8] Johnson A, Brandenberger S, Baccini P. Acid neutralizing capacity of municipal solid waste incinerator bottom ash. Environ Sci Technol 1995;29:142-7.

[9] Van der Sloot HA. Harmonization of leaching/extraction tests and leaching of organic contaminants. Netherlands: ECN Petten, 1998.

[10] Meima JA, Zomeren A, Comans RN. Complexation of $\mathrm{Cu}$ with dissolved organic carbon in municipal solid waste incinerator bottom ash leachates. Environ Sci Technol 1999;33:1424-9.

[11] Tong HY, Shore DL, Karasek FW, Helland P. Jellum E. Identification of organic compounds obtained from incineration of municipal waste by HPLC-Fractionation and GC-MS. 285. 423441 (1984).

[12] Karasek FW, Charbonneau GM, Reuel GJ, Tong HJ. Determination of organic compounds leached from municipal incinerator fly ash by water at different pH levels. APCA Ann Meet 1987; 77(1):84-5.

[13] James RH, Adams RE, Finkel JM, Miller HC. Evaluation of analytical methods for the determination of principal organic hazardous constituents in combustion products. APCA Ann Meet 1984;77(1):84-5.

[14] Priester T, Köster R, Eberle SH. Charakterisierung kohlenstoffhaltiger Bestandteile in Hausmüllverbrennungsschlacken unter besonderer Berücksichtigung organischer Stoffe (Characterization of carbon containing constituents of incinerator bottom ash by special consideration of organic substances). Müll und Abfall 6. 387-398 (1996). 
[15] Dugenest S, Combrisson J, Casabianca H, Grenier-Loustalot MF. Municipal Solid Waste Incineration Bottom Ash: Characterization and kinetic studies of organic matter. Environ Sci Technol 1999;33:1110-5.

[16] Goldberg ED. Black carbon in the environment. Wiley, New York (1985)

[17] Hug P. PhD thesis University. Zurich, Switzerland (1992).

[18] Cadle SH, Groblicki PJ. An evaluation of methods for the determination of organic and elemental carbon in particulate samples. In Wolff G, Klimisch RL. (eds). Particulate carbon. Plenum Press, New York (1982).

[19] Countess RJ. Interlaboratory analyses of carbonaceous aerosol samples. Aerosol Science and Technology 1990;12:114-21.

[20] Gloor R, Leidner H, Wuhrmann K, Fleischmann T. Exclusion chromatography with carbon detection. A tool for further characterization of dissolved organic carbon Water Research 1981;15: 457-62.

[21] Altenbach, B. PhD thesis ETH. Zurich, Switzerland (1996).

[22] Altenbach B, Giger W. Determination of benzene- and naphta- lenesulponates in wastewater by solid-phase extraction with graphitized carbon black and ion-pair chromatography with UVdetection. Anal Chem 1995;67:2325-33.

[23] Belevi H, Langmeier M. Factors determining the element behavior in municipal solid waste incinerators. 2. Laboratory Experiments. Environ Sci Technol 2000;34:2507-12.

[24] Shafizadeh F. Pyrolytic reactions and products of biomass. In Overend RP, Milne TA, Mudge LK. (eds). Fundamentals of thermochemical biomass conversion. Elsevier, London (1985).

[25] Roy C, Chornet EJ. The pyrolysis of peat- a comprehensive review of the literature. Anal Appl Pyrol 1983;5:261-332.

[26] Avni E, Davoudzadeh F, Coughlin RW. Flash pyrolysis of lignin. In Overend RP, Milne TA, Mudge LK. (eds). Fundamentals of thermochemical biomass conversion. Elsevier, London (1985).

[27] Wampler TP. Applied pyrolysis handbook. Marcel Dekker, New York (1995).

[28] Theander O. Cellulose, hemicellulose and extractives. In Overend RP, Milne TA, Mudge LK. (eds). Fundamentals of thermochemical biomass conversion. Elsevier, London (1985). 